\title{
Immobilization of Thiol Proteases onto Porous Poly(vinyl alcohol) Beads
}

\author{
Toshio Hayashi, ${ }^{*}$ Suong-Hyu Hyon, Won-Ill CHA, \\ and Yoshito IKADA \\ Research Center for Biomedical Engineering, Kyoto University, \\ Sakyo-ku, Kyoto 606, Japan.
}

(Received September 16, 1992)

\begin{abstract}
Water-insoluble enzymes were prepared by immobilizing thiol proteases such as, papain, ficin, and bromelain, onto the porous poly(vinyl alcohol) (PVA) beads by covalent fixation. The relative activity (RA) of the immobilized enzymes was found to be rather high toward small ester substrates, $N$-benzyl-L-arginine ethyl ester (BAEE), but rather low toward casein, a high molecular weight substrate. RA of the immobilized enzymes by the hexamethylene diisocianate (HMDI) method gave an almost constant activity in marked contrast with the immobilized enzymes by the cyanogen bromide $(\mathrm{CNBr})$ method whose activity monotonous decreased with the decreasing amount of immobilized enzymes. The values of the Michaelis constant $K_{\mathrm{m}}$ and maximum reaction velocity $V_{\mathrm{m}}$ for free and immobilized enzymes on the porous PVA beads are estimated. Apparent $K_{\mathrm{m}}$ values were larger for immobilized enzymes than for the free ones, while $V_{\mathrm{m}}$ values were smaller for the immobilized enzymes. The $\mathrm{pH}$, thermal, and storage stabilities of the immobilized enzymes were higher than those of the free ones. The initial enzymatic activity of the immobilized enzymes remained almost unchanged without any elimination and inactivation of the enzymes, when the batch enzymatic reaction was performed repeatedly, indicating excellent durability.

KEY WORDS Thiol Protease / Covalent Immobilization / Porous Poly(vinyl alcohol) Bead / Michaelis-Menten Parameters / Stability and Durability /
\end{abstract}

The bioreactor is generally composed of biologically active proteins and their bioinert carriers. A large number of works have been devoted to polymeric carriers, especially the immobilization of proteins to carriers. ${ }^{1}$ Since recovery yield and reusability of free enzymes as industrial catalysts are quite limited, attention has been paid to enzyme immobilization which offers advantages over free enzymes in choice of batch or continuous processes, rapid termination of reactions, controlled product formation, ease of enzyme removal from the reaction mixture, and adaptability to various engineering designs. ${ }^{2,3}$ A concerted or sequential reaction of several enzymes is also possible by the use of mixed or stratified beds. Furthermore, interest in immobilized enzymes and applications to bioprocessing, ${ }^{4,5}$ ana- lytical system, ${ }^{6}$ and enzyme therapy ${ }^{7}$ has steadily grown in the past decade. Thus, many approaches to the preparation of water insoluble enzymes have been explored in recent years ${ }^{8-10}$ to study enzyme reactions in biphasic systems similar to those in vivo.

However, the effects of polymer supports on the activity of enzymes have not been studied in detail until now. In this study, thiol proteases such as, papain, ficin, and bromelain, are selected as hydrolytic enzymes and the polymer support employed is porous poly(vinyl alcohol) (PVA). ${ }^{11}$

The effect of the method of covalent fixation of enzymes onto the porous PVA beads on the hydrolytic activity of the immobilized enzymes is studied. $N$-benzyl-L-arginine ethyl ester (BAEE) is selected as a low molecular 
weight substrate, as well as casein as a high molecular weight substrate, for the enzymatic reaction in this study. The stabilities and durabilities of the immobilized enzymes are also investigated.

\section{EXPERIMENTAL}

\section{Materials}

Porous poly(vinyl alcohol) beads (PVA) were prepared as follows. ${ }^{11}$ Aqueous solutions were prepared from a commercial PVA powder with a degree of polymerization of 1700 and degree of saponification of $99 \mathrm{~mol} \%$. The PVA solutions having a polymer concentration mostly ranging from 10 to $20 \mathrm{wt} \%$ were added dropwise to methylene dichloride to make beads, and were frozen in a refrigerator at $-20^{\circ} \mathrm{C}$. Defreezing of the frozen PVA beads and simultaneous crystallization of PVA phase proceeded slowly at $5^{\circ} \mathrm{C}$. The resulting PVA beads were not soluble in water at room temperature but promptly dissolved

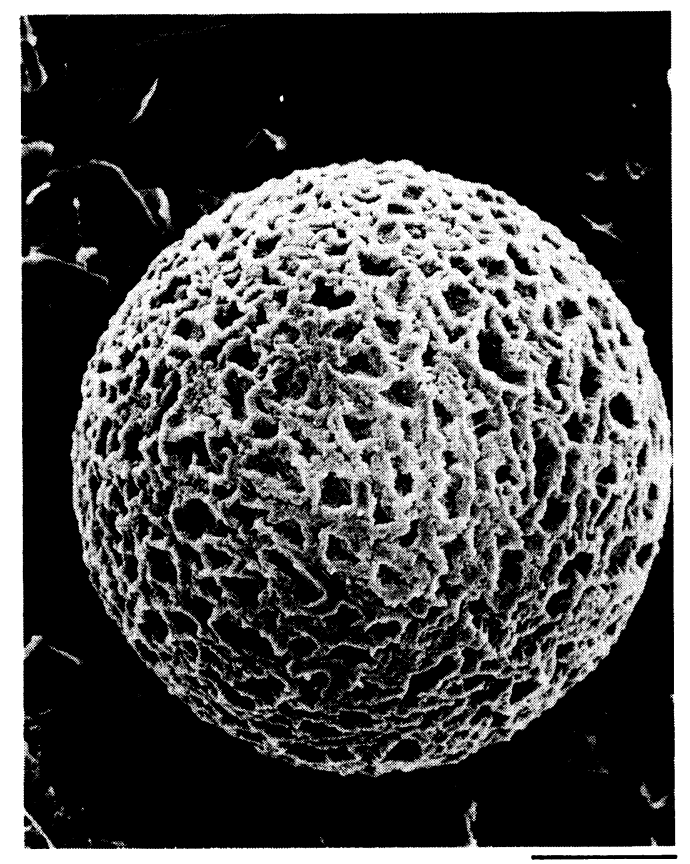

$40 \mu \mathrm{m}$ in water when the temperature was raised to about $70^{\circ} \mathrm{C}$. Figure 1 shows scanning electron micrographs (SEM) of the porous PVA beads.

Papain (3.5 m Anson $\mu \mathrm{g} \mathrm{mg}^{-1}$, Merck), ficin (No.DCP 1402 Wako Pure Chem. Ind., Ltd.), bromelain (EC 3.4.22.4, No. B-2252, Sigma Chem. Co.), $N$-benzyl-L-arginine ethyl ester (BAEE), casein and other chemicals were purchased from Nacalai Tesque Co. (Kyoto, Japan). Casein, as a high molecular weight substrate, was first heated in the $2 \%$ aqueous suspension adjusted to $\mathrm{pH} 8.0$ for $30 \mathrm{~min}$ on a boiling water bath.

\section{Immobilization of Thiol Proteases}

Two covalent fixation methods were employed for the immobilization of enzymes onto the porous PVA beads; hexamethylene diisocianate (HMDI) and cyanogen bromide (CNBr) methods.

Activation of PVA by HMDI was carried out according to a method described elsewhere $^{12}$ as follows. $500 \mathrm{mg}$ of porous PVA

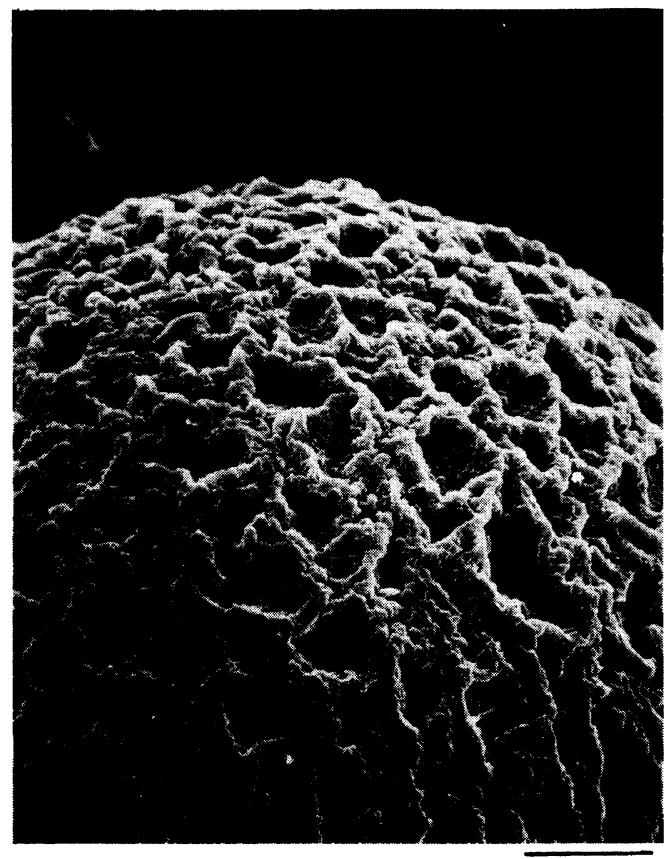

$20 \mu \mathrm{m}$

Figure 1. SEM of the surface of porous PVA beads. 
beads were placed in a three neck round bottom flask and purged with nitrogen gas. $50 \mathrm{ml}$ of distilled toluene solution containing $10 \mathrm{wt} \%$ of HMDI and $0.07 \mathrm{vol} \%$ of di- $n$ butyltin dilaurate were placed in the flask. The reaction mixture was gently stirred for $45 \mathrm{~min}$ under nitrogen gas purging at $25^{\circ} \mathrm{C}$. The activated beads were taken out from the reaction mixture and rinsed successively with distilled toluene and aceton. The beads activated by HMDI were immersed in enzyme solutions ( 1.0 to $8.0 \mathrm{mg} \mathrm{ml}^{-1}$ in $0.1 \mathrm{M}$ PBS at $\mathrm{pH}$ 7.0). The immobilization reactions were allowed to proceed at $20^{\circ} \mathrm{C}$ for a period of $5 \mathrm{~h}$. At predetermined time intervals the beads were taken out from the solutions and washed successively with $\mathrm{HCl}$ aqueous solution of $\mathrm{pH}$ $3.0,0.1 \%$ of aqueous sodium laurylsulfate (SDS) solution, and finally distilled water.

Activation by $\mathrm{CNBr}$ was carried out based on the litearature. ${ }^{13} 500 \mathrm{mg}$ of PVA beads were immersed in $100 \mathrm{ml}$ of $0.2 \mathrm{M}$ sodium carbonate at $4^{\circ} \mathrm{C}$ and gently stirred. To the mixture, $500 \mathrm{mg}$ of $\mathrm{CNBr}$ solved in $1.5 \mathrm{ml}$ of acetonitrile were added all at once. The reaction was allowed to proceed at $4^{\circ} \mathrm{C}$ for given periods of time. After that, the activated PVA beads were taken out from the solution and washed successively with $0.1 \mathrm{M}$ sodium bicarbonate buffer, distilled water, and finally with $0.1 \mathrm{M}$ sodium bicarbonate buffer used for the immobilization reaction.

The immobilization of enzymes onto the PVA beads activated by $\mathrm{CNBr}$ was carried out by immersing the activated PVA beads at $20^{\circ} \mathrm{C}$ in the enzyme solutions at $\mathrm{pH} 9.0$ (1.0 to $8.0 \mathrm{mg} \mathrm{ml}^{-1}$ ). At given time intervals the conjugated beads was taken out and washed successively with $0.1 \mathrm{M}$ sodium acetate, $0.1 \%$ SDS, and distilled water, each for $10 \mathrm{~min}$.

The amounts of enzymes immobilized were determined by the ninhydrin method as follows. The enzyme-immobilized PVA beads were hydrolyzed with $4 \mathrm{~N} \mathrm{HCl}$ in an autoclave under 2.5 atmospheric pressure for $30 \mathrm{~min}$. After that, the hydrolyzed solution was neu- tralized with $3.75 \mathrm{~N} \mathrm{NaOH}$ and ninhydrin solution was added. The absorbance at $570 \mathrm{~nm}$ was measured by Hitachi model 200-20 spectrophotometer. To determine the amounts of enzymes immobilized, the relation between the absorbance at $570 \mathrm{~nm}$ and the amount of protease was predetermined with the original enzymes, and hydrolyzed in the same way as mentioned above. In all measurements, the beads activated but not yet immobilized were used as blank to determine the amount of immobilized enzymes.

\section{Activity Measurements}

The hydrolytic activity of free and immobilized enzymes was determined by using BAEE as a low molecular weight substrate. In $0.05 \mathrm{M}$ PBS at $\mathrm{pH} 8.0,2.5 \mathrm{ml}$ of aqueous BAEE solution were added to $2.5 \mathrm{ml}$ free enzyme solution or $2.5 \mathrm{ml}$ of the immobilized enzyme suspension. To activate each enzyme, $2 \mathrm{mM}$ EDTA and $5 \mathrm{mM}$ cystein were added in PBS. $^{14}$ The final reaction mixture had $2.92 \times$ $10^{-3} \mathrm{M}$ as the substrate concentration. The reaction mixture was maintained at $37.0^{\circ} \mathrm{C}$ under constant stirring, $\mathrm{pH}$ being kept at 8.0 by $0.05 \mathrm{NOH}$ added using a microburet titration. After a predetermined period of time, the enzymatic activity was calculated from the initial rate of BAEE hydrolysis by determining the amount of $\mathrm{KOH}$ consumed within the given period of time. To obtain reproducible activity values, vigorous stirring was necessary, especially for the immobilized enzyme suspensions. Correction was made for non-enzymatic hydrolysis. Three or four different amounts of free enzyme and the immobilized enzyme were used in each activity determination. The activity of the immobilized enzymes was expressed as the relative activity (RA) in percent based on that of free enzymes.

Caseinolytic determinations were made essentially according to Bergmeyer, ${ }^{15}$ with minor modification to overcome special problems encountered with insoluble conjugates. The activities of free and immobilized enzymes 
were determined in the following way. The reaction mixture consisted of $2 \mathrm{ml}$ of $0.01 \mathrm{M}$ PBS at $\mathrm{pH} 8.0,1.0 \mathrm{ml}$ of the free enzyme solution or the immobilized enzyme suspension in $0.05 \mathrm{M}$ PBS, which contained $2 \mathrm{mM}$ EDTA, $5 \mathrm{mM}$ cystein and $1.0 \mathrm{ml}$ of $2.0 \mathrm{wt} \%$ casein solution. The reaction mixture was vigorously stirred at $37^{\circ} \mathrm{C}$ for $20 \mathrm{~min}$, followed by termination with trichloroacetic acid additions to have a concentration of $3.0 \mathrm{wt} \%$. The absorbance of the solution or supernatant at $280 \mathrm{~nm}$ was plotted against enzyme weight to evaluate enzymatic activity.

\section{Stability Measurements}

Thermal stability of the immobilized enzymes was evaluated by measuring the residual activity (ZA) of enzymes exposed to various temperatures in $0.05 \mathrm{M}$ PBS of $\mathrm{pH} 7.4$ for various periods of time. After heating, the samples were quickly cooled and assayed for enzymatic activity at $37.0^{\circ} \mathrm{C}$ immediately or after storage at $4^{\circ} \mathrm{C}$. Storage before the assay ( $30 \mathrm{~min}$ to $48 \mathrm{~h}$ ) did not alter measured activity. Remaining activity was related to the original activities (assayed at $37.0^{\circ} \mathrm{C}$ without heating).

To determine $\mathrm{pH}$ stability, free and immobilized enzymes were incubated in PBS at $37.0^{\circ} \mathrm{C}$ including a definite amount of BAEE substrate, and various $\mathrm{pH}$ regions for $20 \mathrm{~min}$.

To evaluate durabilities of the immobilized enzymes when repeatedly used, the dried immobilized enzymes were washed in $0.05 \mathrm{M}$ PBS two times and then suspended again in a fresh reaction mixture to measure enzymatic activity. This cycle was repeated on the same sample. To check the possibility of any leakage of enzyme molecules under washing, the amount of immobilized enzyme was determined after the last batch test. The storage stability of the free and immobilized enzymes was evaluated by placing enzymes in $0.05 \mathrm{M}$ PBS of $\mathrm{pH} 7.4$ at $25^{\circ} \mathrm{C}$ for various periods of time and the activity was assayed using the above-mentioned techniques.

\section{RESULTS AND DISCUSSION}

Effects of Amounts of Immobilized Enzymes on the Activity

The effects of the initial concentrations of enzymes on the saturated amount of immobilized enzymes were studied to make clear the most adequate initial concentration of enzymes to obtain the highest amounts of immobilized enzymes. Figure 2 illustrates the experimental results obtained with PVApapain system. As is seen in Figure 2, the amount of immobilized papain is almost proportional to the initial papain concentration, at least, in the low concentration level below about $4.0 \mathrm{mg} \mathrm{ml}^{-1}$. Almost the same results were obtained for bromelain and ficin. Finally, in all the following experiments, the initial enzyme concentration was kept at $5.0 \mathrm{mg} \mathrm{ml}^{-1}$, unless otherwise mentioned.

Figure 3 illustrates the effect of the amount of papain immobilized onto PVA beads on RA of BAEE hydrolysis. It is clearly seen that RA of PVA-CNBr-papain decreases gradually with decreasing amount of immobilized papain, especially at an amount of immobilized papain below $0.1 \mathrm{wt} \%$, whereas PVAHMDI-papain gives an almost constant RA even at low surface concentrations, which is markedly higher than that of PVA-CNBrpapain. This may be explained in terms of

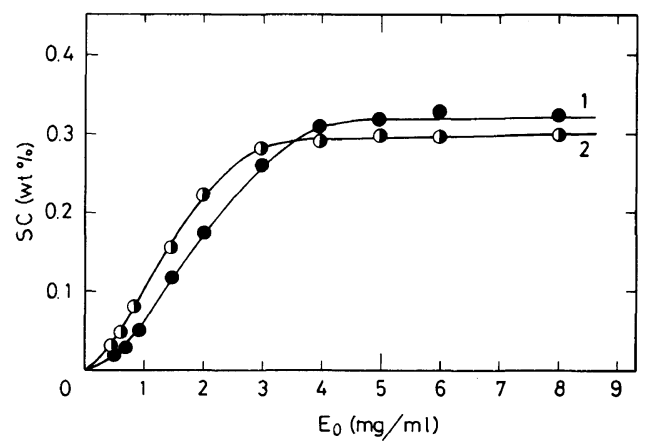

Figure 2. Effects of the initial concentration $\left(E_{o}\right)$ of papain on the amount of immobilized papain (AI) onto PVA beads (wt\%): (1) PVA-CNBr-Pap and (2) PVAHMDI-Pap. 
structural deformation of the immobilized papain molecules as illustrated in Figure 4. Although it is only a speculation, we may consider that covalently immobilized papain by $\mathrm{CNBr}$ method may undergo strong deformation in the region of the lower amount of immobilized enzyme by higher multi-point fixation between the enzyme molecule and active points of the activated PVA-CNBr

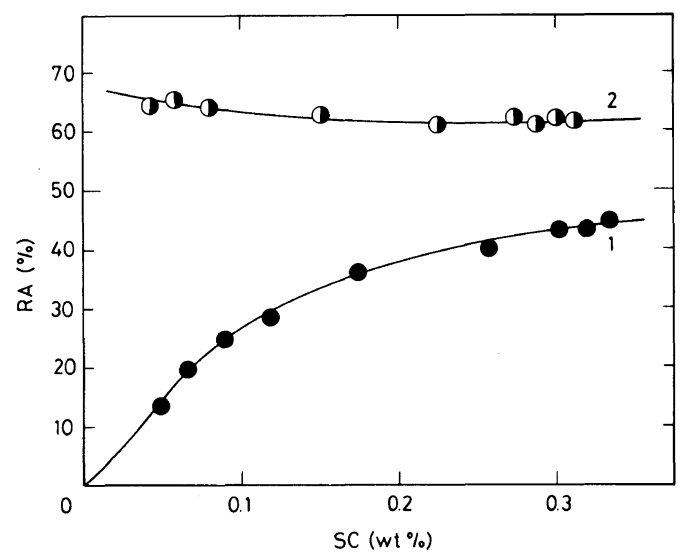

Figure 3. Effects of the amount of immobilized papain $(w \mathrm{t} \%)$ on the relative activities (RA). (Hydrolysis: BAEE, pH 8.0, and $37.0^{\circ} \mathrm{C}$ ). (1) PVA-CNBr-Pap and (2) PVA-HMDI-Pap.
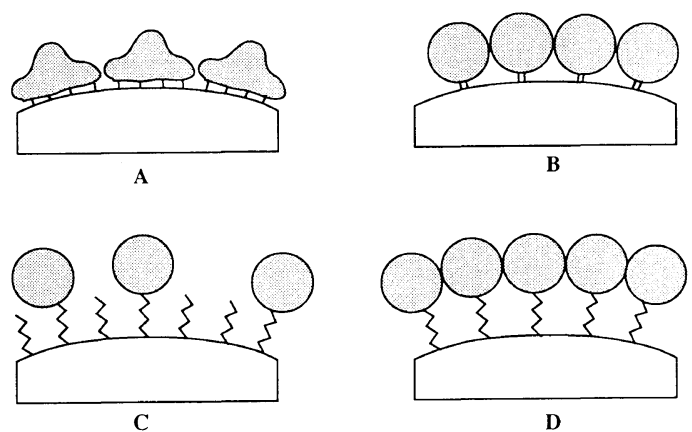

Figure 4. Schematic representation for the molecular state of enzymes immobilized onto PVA beads: A and B denote that of PVA-CNBr-enzyme for (A) sparse immobilization and (B) dense immobilization of enzyme molecules, and $\mathrm{C}$ and D denote that of PVA-HMDIenzyme for (C) sparse immobilization and (D) dense immobilization of enzyme molecules. beads than that of the HMDI method. On the other hand, the immobilized papain molecule by the HMDI method may be protected from the heavy structural deformation even in the lower region of the amounts of immobilized enzymes owing to the spacer effects of HMDI molecules; that is, the adequate length of HMDI molecule may work to prevent excess multi-point fixation between the enzyme molecule and the activated PVA-HMDI beads. Furthermore, low RA of papain immobilized by $\mathrm{CNBr}$ method even in the higher region of the amount of immobilized enzyme is said to result from reduced interaction with the substrate compared to that of papain immobilized by the HMDI method.

\section{Determination of Michaelis Constants}

It seems interesting to analyze the enzymatic hydrolysis with the immobilized enzyme in the framework of the Michaelis-Menten mechanism, although the enzyme reaction takes place apparently in a heterogeneous state. It was already shown experimentally that the first-order relation was obtained between the hydrolytic activity and enzyme concentration with both free and immobilized enzymes in the previous paper. ${ }^{16-18}$

Initial reaction rates were determined at

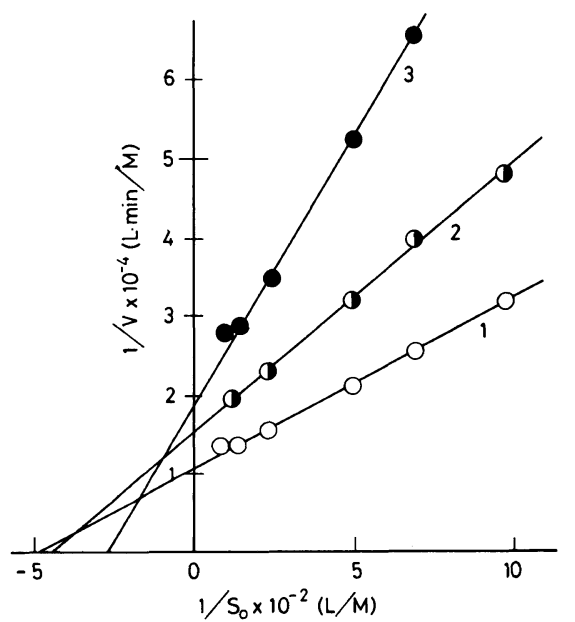

Figure 5. Lineweaver-Burk plots of $1 / V$ vs. $1 / S$. (1) free papain; (2) PVA-HMDI-Pap-1; (3) PVA-CNBr-Pap-1. 
different BAEE concentrations ranging from 1.00 to $10.0 \mathrm{mM}$. Figure 5 shows LineweaverBurk plots for free and immobilized papain. The values of the Michaelis constant $K_{\mathrm{m}}$ and maximum reaction velocity $V_{\mathrm{m}}$ for the free and the immobilized papain on PVA beads are estimated from Figure 5 and tabulated in Table I together with the experimental results for bromelain and ficin. The apparent $K_{\mathrm{m}}$ values of the immobilized enzymes were higher than that of the free one. This may

Table I. Relative activity of immobilized enzymes

\begin{tabular}{|c|c|c|c|}
\hline \multirow{2}{*}{ Sample code } & \multirow{2}{*}{$\frac{\mathrm{SC}}{\mathrm{wt} \%}$} & \multicolumn{2}{|c|}{$\mathrm{RA} / \%$} \\
\hline & & BAEE & Casein \\
\hline Native papain & & 100 & 100 \\
\hline PVA/Pap-1 & 0.65 & 75 & 40 \\
\hline PVA/Pap-2 & 0.10 & 72 & 39 \\
\hline PVA-CNBr-Pap-1 & 0.32 & 44 & 11 \\
\hline PVA-CNBr-Pap-5 & 0.09 & 24 & 8 \\
\hline PVA-HMDI-Pap-1 & 0.30 & 62 & 19 \\
\hline PVA-HMDI-Pap-5 & 0.08 & 64 & 20 \\
\hline Native bromelain & & 100 & 100 \\
\hline PVA/Bro-1 & 0.62 & 70 & 34 \\
\hline PVA-CNBr-Bro-1 & 0.27 & 40 & 13 \\
\hline PVA-HMDI-Bro-1 & 0.25 & 54 & 22 \\
\hline Native ficin & & 100 & 100 \\
\hline PVA/Fic-1 & 0.66 & 74 & 37 \\
\hline PVA-CNBr-Fic-1 & 0.26 & 38 & 10 \\
\hline PVA-HMDI-Fic-1 & 0.24 & 50 & 18 \\
\hline
\end{tabular}

Table II. Michaelis parameters $K_{\mathrm{m}}$ and $V_{\mathrm{m}}{ }^{\text {a }}$ (BAEE hydrolysis, $\mathrm{pH} 8.0$ and $37.0^{\circ} \mathrm{C}$ )

\begin{tabular}{lrrr}
\hline \multirow{2}{*}{ Sample code } & \multicolumn{1}{c}{$K_{\mathrm{m}}$} & & $V_{\mathrm{m}}$ \\
\cline { 2 - 2 } & $\mathrm{M} \mathrm{1}^{-1}$ & & $\mathrm{M} \mathrm{min}^{-1} \cdot 1^{-1}$ \\
\hline Native papain & $2.0 \times 10^{-3}$ & & $9.4 \times 10^{-5}$ \\
PVA-CNBr-Pap-1 & $3.8 \times 10^{-3}$ & & $4.6 \times 10^{-5}$ \\
PVA-HMDI-Pap-1 & $2.8 \times 10^{-3}$ & & $6.5 \times 10^{-5}$ \\
Native bromelain & $8.0 \times 10^{-3}$ & & $4.3 \times 10^{-5}$ \\
PVA-CNBr-Bro-1 & $13.8 \times 10^{-3}$ & & $2.0 \times 10^{-5}$ \\
PVA-HMDI-Bro-1 & $9.8 \times 10^{-3}$ & & $2.6 \times 10^{-5}$ \\
Native ficin & $7.8 \times 10^{-3}$ & & $1.9 \times 10^{-5}$ \\
PVA-CNBr-Fic-1 & $11.2 \times 10^{-3}$ & & $0.8 \times 10^{-5}$ \\
PVA-HMDI-Fic-1 & $9.0 \times 10^{-3}$ & & $1.1 \times 10^{-5}$ \\
\hline
\end{tabular}

${ }^{a}$ Enzyme concentration $[E]=6.0 \times 10^{-7}\left(\mathrm{M}^{-1}\right)$. be due to the limitation of diffusion resistance. On the other hand, $V_{\mathrm{m}}$ of the immobilized enzyme was lower than that of the free one. RA of the immobilized enzymes may decrease in the course of covalent fixation, especially in the $\mathrm{CNBr}$ method.

\section{Effect of $p H$ on Activity}

The $\mathrm{pH}$ dependence of RA of the immobilized enzyme was compared with that of the free enzymes for BAEE hydrolysis in various $\mathrm{pH}$ regions at $37^{\circ} \mathrm{C}$ in PBS. Figure 6 shows experimental results of the PVA-papain system, where it is seen that the immobilized papain has the same optimum $\mathrm{pH}$ as the free one but the $\mathrm{pH}$ range where the enzyme with high activity is considerably widened compared to that of the free one, probably due to diffusional limitations of the immobilized enzyme molecules. ${ }^{19}$

\section{Thermal Stability of the Immobilized Enzymes}

The thermal stability of immobilized enzymes is one of the most important criteria for application. As is well known, the activity of immobilized enzymes, especially in covalently bound systems, is more resistant against heat and denaturing agents than that of the soluble form. ${ }^{20}$ The effects of temperature on the stability of the immobilized papain in PBS are

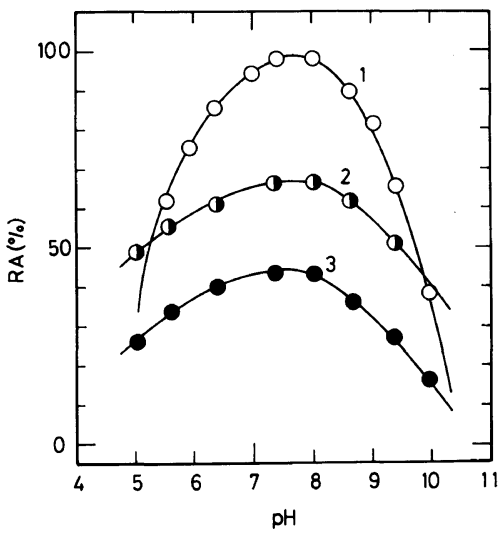

Figure 6. Effects of $\mathrm{pH}$ of the reaction medium on the relative activity (RA) of BAEE hydrolysis at $37^{\circ} \mathrm{C}$ : (1) free papain; (2) PVA-HMDI-Pap-1; (3) PVA-CNBr-Pap-1. 
Table III. Effects of heat treatment on residual activity

\begin{tabular}{ccccc}
\hline Temp $^{\mathrm{a}}$ & & \multicolumn{3}{c}{ Residual activity ZA/\% } \\
\cline { 1 - 2 } \cline { 4 - 5 }${ }^{\circ} \mathrm{C}$ & & $\begin{array}{c}\text { Free } \\
\text { papain }\end{array}$ & $\begin{array}{c}\text { PVA-HMDI- } \\
\text { Pap-1 }\end{array}$ & $\begin{array}{c}\text { PVA-CNBr- } \\
\text { Pap-1 }\end{array}$ \\
\hline 30.0 & & 100 & 100 & 100 \\
37.0 & & 100 & 100 & 100 \\
50.0 & 93 & 98 & 100 \\
55.0 & 87 & 97 & 100 \\
60.0 & 70 & 95 & 99
\end{tabular}

${ }^{a}$ Pre-heat temperature, $1 \mathrm{~h}$ at $\mathrm{pH} 8.0$ in $0.1 \mathrm{M}$ PBS.

$\mathrm{ZA}$ of BAEE hydrolysis at $\mathrm{pH} 8.0$ and $37.0^{\circ} \mathrm{C}$ in $0.1 \mathrm{M}$ PBS.

shown in Table III. The immobilized papain is more stable than free ones in the range of higher temperatures. For example, the residual activity (ZA) of the immobilized papain after being treated at $60^{\circ} \mathrm{C}$ for $60 \mathrm{~min}$ remained almost unchanged, while that of the free papain decreased to $70 \%$ the original value.

The immobilized papain onto PVA beads by HMDI method is slightly less stable than that by $\mathrm{CNBr}$ method (Table III). This may be due to the higher multi-point attachment of the papain molecule onto PVA beads by the $\mathrm{CNBr}$ method with reduced molecular mobility of the papain than that by the HMDI method.

\section{Storage Stability}

Aqueous suspensions of the immobilized enzymes could be stored at $4^{\circ} \mathrm{C}$ for 6 months without a significant loss of activity, whereas the corresponding free enzymes lost of their initial activity rather fastly under the same conditions. The higher stability of the immobilized enzymes can be attributed to the prevention of autodigestion and thermal denaturation as a result of the fixation of enzyme molecules onto polymeric carriers. Furthermore, it is often pointed out that the lyophilization of enzymes directly from the water suspensions is normally accompanied by loss of enzymatic activity. Thus, enzymatic
Table IV. Residual activity (ZA) after lyophilization

\begin{tabular}{lccccc}
\hline \multirow{2}{*}{ Sample code } & \multirow{2}{*}{$\mathrm{SC}$} & & \multicolumn{2}{c}{ ZA/\% } \\
\cline { 2 - 2 } \cline { 5 - 5 } \cline { 5 - 5 } & $\mathrm{wt} \%$ & & BAEE & Casein \\
\hline Native papain & - & & 75 & 70 \\
PVA-HMDI-Pap-1 & 0.30 & & 94 & 92 \\
PVA-CNBr-Pap-1 & 0.32 & & 98 & 95 \\
Native bromelain & - & & 72 & 68 \\
PVA-HMDI-Bro-1 & 0.25 & & 93 & 90 \\
PVA-CNBr-Bro-1 & 0.27 & & 96 & 94 \\
Native ficin & - & & 70 & 67 \\
PVA-HMDI-Fic-1 & 0.24 & & 90 & 88 \\
PVA-CNBr-Fic-1 & 0.26 & & 95 & 92
\end{tabular}

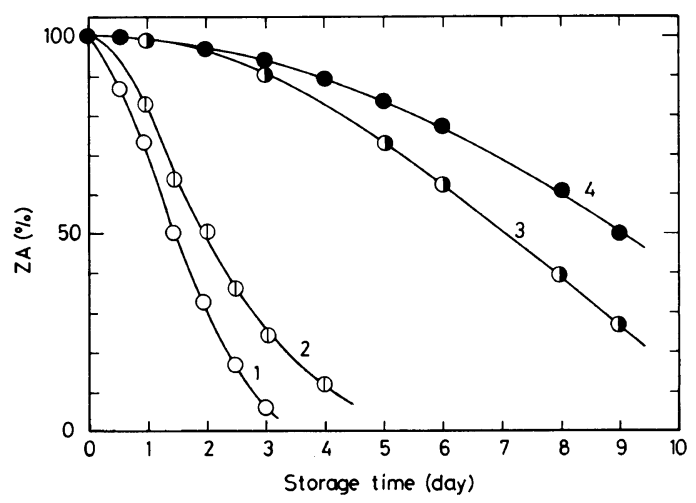

Figure 7. Effects of storage time in PBS at $\mathrm{pH} 7.4$ and $37^{\circ} \mathrm{C}$ on the residual activity (ZA) of BAEE hydrolysis at pH 8.0 and $37^{\circ} \mathrm{C}$ : (1) free papain; (2) papain adsorbed on PVA beads; (3) PVA-HMDI-Pap-1; (4) PVA-CNBrPap-1.

activity retained after lyophilization of the immobilized and free enzymes was determined. Very high ZA is observed for immobilized enzymes with BAEE hydrolysis as shown in Table IV.

It is of interest to point out that there is a similarity between the thermal and storage stability to lyophilization.

It is reported that hydrophilic carriers such as Sephadex, Sepharose, and polyacrylamide yield enzyme derivatives of high lyophilization and thermal stabilities. ${ }^{21-23}$ PVA beads are hydrophilic carriers.

To examine enzymatic stability in the con- 


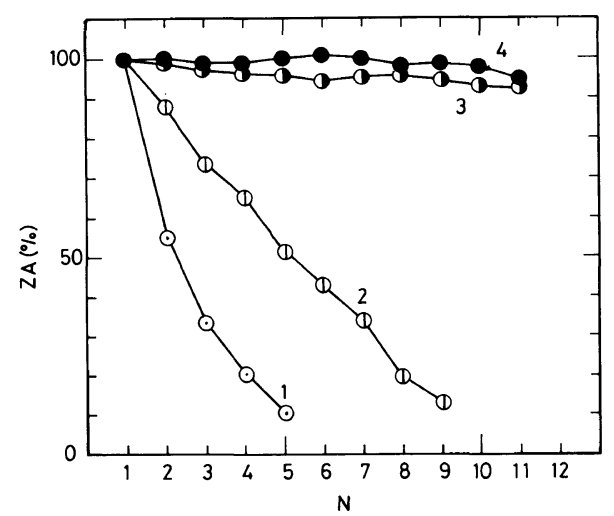

Figure 8. Effects of the repeated use of the immobilized papain on residual activity (ZA). (Hydrolysis: BAEE, $\mathrm{pH}$ 8.0, and $37.0^{\circ} \mathrm{C}$.) (1) papain adsorbed on PVA beads; (2) papain adsorbed on PVA beads and GA treatment; (3) PVA-HMDI-Pap-1, and (4) PVA-CNBr-Pap-1.

tinuous reaction system under a rather drastic condition, effects of the storage in PBS of $\mathrm{pH}$ 7.4 at $37.0^{\circ} \mathrm{C}$ were studied for immobilized enzymes. ZA of thiol proteases such as papain may decrease due to autodigestion. Figure 7 illustrates experimental results obtained with ZA for BAEE hydrolysis by PVA-papain system. It is apparent that the immobilized papain by covalent fixation is much more stable than the free one. Again, the immobilized papain by $\mathrm{CNBr}$ method shows slightly more stable activity than that by the HMDI method.

\section{Durability for Repeated Use}

The durability of the immobilized enzymes is also important in application because they are subjected to repeated hydrolysis reactions. Figure 8 illustrates the effects of repeated use on ZA of BAEE hydrolysis by immobilized papain. The activity of the immobilized papain by covalent fixation is retained without definite loss, even if the batch reaction is repeated 11 times.

It was found that the amount of the immobilized papain by covalent fixation after the last batch was equivalent to the original one within the experimental error in each cases, suggesting that no leakage of the immobilized papain occurs by repeated washings. This high stability is in marked contrast with the rather poor durability of the papain immobilized by adsorbance on the porous PVA beads, even though glutalaldehyde treatment was performed.

\section{CONCLUSION}

Immobilized thiol proteases, such as papain, bromelain, and ficin, onto the porous PVA beads by covalent fixation gave rather high activity toward a small ester substrates, BAEE, whereas still lower activity toward casein, a high molecular weight substrate. RA of the immobilized enzymes by $\mathrm{CNBr}$ method decreased gradually with decreasing amounts of immobilized enzymes. On the other hand, immobilized enzymes by the HMDI method gave almost constant activity for the substrate hydrolysis even at lower amounts of immobilized enzyme. The apparent $K_{\mathrm{m}}$ values were larger for immobilized enzymes than for the free ones, while $V_{\mathrm{m}}$ values were smaller for the immobilized enzymes.

$\mathrm{pH}$, thermal, and storage stability of the immobilized enzymes were higher than those of the free one. The initial enzymatic activity of the immobilized enzymes by covalent fixation remained almost unchanged, without elimination or inactivation of the enzymes, indicating excellent durability of bound enzyme molecules.

\section{REFERENCES}

1. J. F. Kennedy, C. A. White, and E. H. M. Melo, Chimicaoggi-Maggio, 21 (1988).

2. R. Axen, in "Insolubilized Enzyme," M. Salmona, C. Soronio, and S. Garattini, Ed., Raven Press, New York, 1974, p 9.

3. E. K. Katchalski, in "Enzyme Engineering," H. H. Weetall and G. P. Royer, Ed., Prenum Press, New York, N.Y., 1982, p 12.

4. P. Linko and Y. Y. Linko, Critical Reviews in Biotechnology, 1, 289 (1984).

5. I. Chibata, T. Tosa, and T. Sato, in "Biotechnology," 
Vol.7-a, Enzyme Technology, J. F. Kennedy, Ed., VCH Verlagsgesellschaft, Weinheim, 1987, p 653.

6. F. Senatore, F. Bernath, and K. Meisner, $J$. Biomed. Mater. Res., 20, 177 (1986).

7. Y. Arica and V. N. Hasirci, Biomaterials, 8, 489 (1987).

8. R. Sipehia, A. S. Chawla, J. Daka, and T. M. S. Chang, J. Biomed. Mater. Res., 22, 417 (1988).

9. R. Axen and S. Ernback, Eur. J. Biochem., 18, 351 (1971).

10. A. Kozhukharova, N. Kirova, Y. Popova, K. Batsalova, and K. Kunchev, Biotech. Bioeng., 32, 245 (1988).

11. S.-H. Hyon, W.-I. Cha, and Y. Ikada, Kobunshi Ronbunshu, 46, 673 (1989).

12. M. Taniguchi, R. K. Samal, M. Suzuki, H. Iwata, and Y. Ikada, Am. Chem. Soc., Symp. Ser., 187, 217 (1982).

13. S. C. March, I. Parikh, and P. Cuatrecasas, Anal. Biochem., 60, 149 (1974).
14. M. Kumakura and I. Kaetsu, Polym. J., 16, 113 (1984).

15. H. Bergmeyer, in "Methods of Enzymatic Analysis," Academic Press, New York and London, 1963.

16. T. Hayashi and Y. Ikada, Biotech. Bioeng., 35, 518 (1990).

17. T. Hayashi and Y. Ikada, Biotech. Bioeng., 36, 593 (1990).

18. T. Hayashi, C. Hirayama, and M. Iwatsuki, J. Appl. Polym. Sci., 44, 143 (1992).

19. P. F. Greenfield and R. L. Laurence, J. Food Sci., 40, 906 (1975).

20. R. Ulbrich, A. Schellenberger, and W. Damerau, Biotech. Bioeng., 28, 511 (1986).

21. L. Goldstein, Biochim. Biophys. Acta, 315, 1 (1973).

22. D. Gebel and B. V. Hofsten, Eur. J. Biochem., 15, 410 (1970).

23. D. Gebel, I. Z. Steinberg, and E. Katchalski, Biochemistry, 10, 4661 (1971). 